\title{
PENYAKIT AKIBAT KERJA BAGI PERAWAT YANG BERTUGAS DI RUMAH SAKIT
}

\author{
Inayah Husna Sibarani / inayahhusna08@gmail.com
}

\section{LATAR BELAKANG}

Dalam kehidupan manusia selalu mengadakan berbagai macam aktifitas. Salah satu aktivitas yang rutin dilakukan setiap orang adalah bekerja. Bekerja dapat diartikan sebagai kegiatan manusia dalam melaksanakan suatu tugas yang diakhiri dengan buah karya yang dapat dinikmati oleh manusia yang bersangkutan. Apapun profesi yang dipilih, bekerja bagi setiap orang selalu dilakukan dalam rangka memenuhi kebutuhan sehari-hari, mulai dari pekerjaan yang berisiko rendah hingga pekerjaan yang berisiko tinggi.

Perawat merupakan petugas kesehatan dengan presentasi terbesar dan memegang peranan penting dalam pemberian pelayanan kesehatan. Dalam menjalankan tugasnya perawat berisiko mengalami gangguan kesehatan dan keselamatan kerja (K3).

Perawat merupakan petugas kesehatan dengan presentasi terbesar dan memegang peranan penting dalam pemberian pelayanan kesehatan. WHO (2013) mencatat, dari 39,47 juta petugas kesehatan di seluruh dunia, 66,7\% nya adalah perawat. Di Indonesia, perawat juga merupakan bagian terbesar dari tenaga kesehatan yang bertugas di rumah sakit yaitu sekitar 47,08\% dan paling banyak berinteraksi dengan pasien (Depkes RI, 2014).

Kecelakaan adalah kejadian tidak terduga yang disebabkan oleh tindakan tidak aman dan kondisi tidak aman (Heinrich, 1930). Sebagian besar (85\%) kecelakaan disebabkan oleh faktor manusia dengan tindakan yang tidak aman. Ancaman kecelakaan kerja di tempat kerja di negara berkembang seperti Indonesia masih sangat tinggi. Hasil laporan National Safety Council tahun 1988 menunjukkan bahwa terjadinya kecelakaan kerja di rumah sakit 41\% lebih besar dari pekerja industri lainnya. Kasus yang sering terjadi adalah tertusuk jarum, terkilir, sakit pinggang, tergores, luka bakar dan penyakit infeksi lainnya.

Kejadian penyakit infeksi di rumah sakit dianggap sebagai suatu masalah serius karena mengancam kesehatan dan kesejahteraan pasien dan petugas kesehatan secara global (Luo, et all, 2010). Penelitian menunjukan bahwa rata-rata risiko transmisi virus melalui Blood-borne pada kecelakaan tertusuk jarum yaitu 30\% untuk virus Hepatitis B, virus Hepatitis C yaitu 3\% 
dan kurang lebih 0,3\% untuk virus HIC (Weston, 2008). WHO (2002) mengestimasikan bahwa sekitar 2,5\% petugas kesehatan diseluruh dunia menghadapi pajanan HIV dan sekitar 40\% menghadapi pajanan virus Hepatitis B dan Hepatitis C (Sadoh, et. all, 2006) dan 90\% dari infeksi yang dihasilkan dari pajanan tersebut berada di negara berkembang (Reda, et.all, 2010).

\section{METODE}

Kajian ini menggunakan metode kualitatif, metode ini bersifat memberikan penjelasan dengan membuat analisis. Proses pengkajian ini lebih menggunakan landasan teori dengan mengumpulkan data, bereksplorasi bebas yang telah disimpulkan dari berbagai sumbersumber, yaitu buku, majalah, koran, jurnal print maupun jurnal online bertema perencanaan keperawatan. Saya membaca dari berbagai referensi berupa buku, jurnal print maupun jurnal online. Melalui metode ini saya memahami dan mengidentikasi penyakit akibat kerja bagi perawat yang sedang bertugas. Kemudian mengetahui apa saja hal atau penyakit yang akan terjadi. Serta kita dapat mengetahui upaya dalam pencegahannya.

\section{HASIL}

Berdasarkan hasil, penyakit akibat kerja disebabkan oleh tindakan tidak aman yang dilakukan perawat. Seperti, tidak memakai APD, tidak mengikuti prosedur kerja, tidak mengikuti peraturan keselamatan kerja dan bekerja tidak hati-hati, dimana dari setiap 300 tindakan tidak aman, akan terjadi 1 (satu) kali kecelakaan yang mengakibatkan kehilangan hari kerja.

Perilaku tidak aman perawat saat bekerja tanpa menggunakan alat pelindung diri sesuai standar dapat mengakibatkan kecelakaan kerja dan menimbulkan penyakit akibat kerja. Cedera akibat tusukan jarum pada perawat merupakan masalah yang signifikan dalam institusi pelayanan kesehatan dewasa ini. Ketika perawat tanpa sengaja menusuk dirinya sendiri dengan jarum suntik yang sebelumnya masuk ke dalam jaringan tubuh pasien, perawat beresiko terjangkit sekurang-kurangnya 20 patogen potensial. Dua pathogen yang paling menyebabkan masalah ialah hepatitis B (HBV) dan Human Immunodeficiency Virus atau HIV. Hepatitis B adalah penyakit infeksi pada hati (hepar/liver) yang berpotensi fatal yang disebabkan oleh Virus Hepatitis B (VHB) dan merupakan salah satu penyakit yang sering ditemui dan menular. Penularannya sangat cepat, 100 kali lebih cepat dari HIV/AIDS dan dapat menyebabkan kematian.

Faktor pengalaman pada tugas yang sama dan lingkungan yang sudah dikenal dapat mempengaruhi perawat tersebut berperilaku tidak aman karena menyenangkan, nyaman dan 
menghemat waktu dan perilaku ini cenderung berulang. Hal ini membuktikan bahwa perawat yang mempunyai pengalaman kerja lebih lama cenderung kurang berhati-hati karena merasa bisa menguasai semua jenis pekerjaan sehingga sering bertindak sembrono dan tidak memperhatikan prinsip dasar keselamatan dalam bekerja. Sedangkan pengalaman kerja yang masih kurang pada perawat baru dan besarnya pengaruh lingkungan tempat kerja menyebabkan terbentuknya unsafe action, karena apabila perilaku yang biasa dilihat adalah cenderung kearah unsafe maka secara sadar/tidak perawat tersebut akan mengadop perilaku tersebut, begitupun sebaliknya.

\section{PEMBAHASAN}

Faktor-faktor penyebab penyakit akibat kerja dapat dibedakan sebagai berikut:

a. Faktor Fisik, yang meliputi:

1) Suara tinggi/bising yang dapat menyebabkan ketulian.

2) Temperatur/suhu tinggi yang dapat menyebabkan Hyperpireksi, Milliaria, heat Cramp, Heat Exhaustion, Heart Stroke.

3) Radiasi sinar elektromagnetik, pada mata infra merah dapat menyebabkan katarak, ultraviolet menyebabkan konjungtivitis, radioaktif/ alfa/ beta/ gama/ X menyebabkan gangguan terhadap sel tubuh manusia.

4) Tekanan udara tinggi yang dapat menyebabkan Coison Disease.

5) Getaran/vibration yang dapat menyebabkan Reynaud's Disease, Gangguan proses metabolisme, Polineurutis.

b. Faktor Kimia

1) Berasal dari bahan baku, bahan tambahan, hasil antara, hasil samping, hasil (produk), sisa produksi atau bahan buangan yang dapat berbentuk zat padat, cair, gas, uap maupun partikel. Materi ini masuk ke tubuh dapat melalui saluran pernafasan, saluran pencernaan, kulit dan mukosa.

2) Efek terhadap tubuh dapat menyebabkan iritasi, alergi, korosif, Asphyxia, keracunan sistemik, kanker, kerusakan/kelainan janin, pneumoconiosis, efek bius (narkose) dan pengaruh genetik.

c. Faktor biologi yang dapat berasal dari: virus, bakteri, parasit, jamur, serangga, binatang buas, dan lain-lain.

d. Faktor Ergonomi/Fisiologi

1) Penyebabnya adalah cara kerja, posisi kerja, alat kerja, lingkungan kerja yang salah dan kontruksi salah. 
2) Efek terhadap tubuh yaitu dapat menyebabkan kelelahan fisik, nyeri otot, deformitas tulang, perubahan bentuk dan dislokasi.

e. Faktor Mental/Psikologi: Penyebabnya yaitu suasana kerja monoton dan tidak nyaman, hubungan kerja kurang baik, upah kerja kurang, terpencil, atau tak sesuai bakat yang mengakibatkan stress.

Setiap tindakan yang dilakukan oleh perawat mempunyai potensi bahaya berupa bahaya fisik, biologi, dan ergonomi. Bahaya fisik didapatkan pada pekerjaan yang menggunakan alat yang tajam, seperti memasang infus dan menjahit luka. Bahaya biologi terdapat pada tindakan invasif, merawat luka, memasang infuse, dan memberikan obat melalui rektal. Sedangkan postur janggal ketika membungkuk merupakan bahaya pekerjaan karena faktor ergonomi.

Bahaya ergonomi merupakan salah satu potensi bahaya dalam K3 yang kurang menjadi perhatian dalam suatu tempat kerja. Padahal bahaya ergonomi dapat menimbulkan kerugian di tempat kerja, dimana bahaya ergonomi dapat mengakibatkan produktivitas dan kualitas pekerja menurun serta dapat menimbulkan penyakit akibat kerja.

Potensi bahaya pada tindakan ini adalah tertusuk jarum infus dan terpapar darah pasien yang terjadi karena ketika jarum ditusukkan ke vena, pasien bergerak dan mengenai jari perawat atau yang melakukan pembendungan pada pembuluh darah yang akan diinfus (stuwing) atau bisa juga karena setelah pemasangan, jarum tidak ditutup atau waktu menutup menggunakan dua tangan.

Apabila tertusuk jarum yang sudah dipakai, maka berisiko tertular HIV walaupun persentasenya kecil dengan persentase 1\%. Bahaya lain yang teridentifikasi adalah bahaya sarana kerja, seperti tempat tidur yang rendah karena pengatur tinggi rendahnya tidak berfungsi sehingga perawat dalam bekerja harus membungkuk 900 yang dapat menyebabkan low back pain.

Pada tindakan menjahit luka, bahaya yang teridentifikasi adalah luka kena pecahan ampul obat anestesi. Bahaya ini terjadi pada tahap menyiapkan obat anestesi, perawat memecahkan ampul obat tanpa menggunakan APD atau pelindung lain sehingga pecahan ampul obat langsung mengenai jari tangan. Tertusuk jarum jahit terjadi pada tahap penjahitan luka, hal ini terjadi karena perawat menjahit tidak menggunakan pinset untuk menahan tepi luka, tetapi menggunakan jari tangannya sendiri. Bahaya lain yang teridentifikasi adalah posisi kerja yang tidak normal sehingga perawat harus membungkuk, postur tubuh yang janggal ini karena sarana kerja yang tidak ergonomi.

Adanya hubungan persepsi keselamatan dan kesehatan kerja dengan perilaku K3, memberikan bukti bahwa peran kesadaran pekerja dalam menilai dan memberikan makna 
terhadap kondisi lingkungan kerja di area produksi terkait bahaya-bahaya yang dapat menyebabkan kecelakaan kerja, sangat penting agar terwujudnya perilaku keselamatan yang semakin baik.

Kondisi fisik yang tidak prima dapat mengurangi kapasitas kerja dan ketahanan tubuh pekerja. Penurunan konsisi fisik pada perawat ditandai dengan ditandai dengan berkurangnya kemauan untuk bekerja yang sebabnya adalah persyaratan psikis. Penyebab kelelahan umum adalah monotoni, intensitas, dan lamanya kerja mental dan fisik, keadaan lingkungan.

Perawat yang sedang merawat pasien mengidap penyakit TB dan ia tidak memakai APD yang lengkap, salah satunya masker. Maka, perawat tersebut bisa saja tertular penyakit TB. Tuberkulosis (TB) adalah penyakit menular yang disebabkan oleh basilbakteri dari Mycobacterium Tuberculosa. Tuberkulosis terutama menyerang paru-paru yang disebut TB paru dapat juga menyerang organ lain seperti meninges, ginjal, tulang, usus, pleura, kandung kemih dan saluran kemih juga kelenjar getah bening yang disebut TB ekstra paru (WHO, 2011). Sebagian besar kasus baru TB, salah satunya terjadi pada Asia, termasuk Indonesia, salah satu negara di Wilayah Asia Tenggara (Villamor et al, 2008).

Pencegahan kecelakaan kerja dapat dilakukan dengan (1) pengamatan resiko bahaya di tempat kerja, (2) pelaksanaan SOP secara benar di tempat kerja, (3) pengendalian faktor bahaya di tempat kerja, (4) peningkatan pengetahuan tenaga kerja terhadap keselamatan kerja dan (5) pemasangan peringatan bahaya kecelakaan di tempat kerja. Selain itu upaya pencegahan kecelakaan kerja juga perlu disediakan sarana untuk menanggulangi kecelakaan di tempat kerja seperti penyediaan $\mathrm{P} 3 \mathrm{~K}$, penyediaan peralatan dan perlengkapan tanggap darurat (Cecep, 2014).

Menurut Honda dkk (2014) dalam penelitian di Thailand, terdapat hubungan yang signifikan antara sikap perawat terhadap pencegahan cidera/ kecelakaan akibat benda tajam dan terjadinya cidera akibat benda tajam. Perawat yang memiliki sikap negative terhadap pencegahan cidera benda tajam hampir dua kali cenderung terkena cidera benda tajam dibandingkan dengan yang bersikap positif. Rumah sakit dapat mengurangi jumlah kejadian tertusuk benda tajam dengan meningkatkan sikap perawat dimana sikap sangat berhubungan dengan perilaku. Penelitian ini sesuai juga dengan penelitian yang dilakukan oleh Sandewa dan Adhiwijaya (2014) bahwa sikap ada hubungan dengan kejadian kecelakaan kerja.

Potensi KAK yang terbesar disebabkan kesalahan atau kelalaian dari karyawan yang tidak menggunakan APD dalam bekerja. Walaupun pengawas sudah memberitahukan dan menyarankan menggunakan APD dapat menghindari terjadinya KAK, tetapi masih ada karyawan yang tidak menghiraukannya. Bahkan pengawas juga tidak memberikan sanksi atau 
teguran karena karyawan merasa kurang nyaman atau kurang dapat bergerak secara leluasa saat bekerja.

Keselamatan dan kesehatan kerja adalah upaya untuk memberikan jaminan keselamatan dan meningkatkan derajat kesehatan para pekerja dengan cara pencegahan kecelakaan dan penyakit akibat kerja, pengendalian bahaya di tempat kerja, promosi kesehatan, pengobatan dan rehabilitasi. Peran kesehatan dan keselamatan kerja dalam ilmu kesehatan kerja berkontribusi dalam upaya perlindungan kesehatan para pekerja dengan upaya promosi kesehatan, pemantauan, dan survei kesehatan serta upaya peningkatan daya tahan tubuh dan kebugaran pekerja. Sementara peran keselamatan adalah menciptakan sistem kerja yang aman atau yang mempunyai potensi risiko yang rendah terhadap terjadinya kecelakaan dan menjaga aset perusahaan dari kemungkinan loss (Rejeki, 2015).

\section{PENUTUP}

Perawat merupakan tenaga kesehatan yang paling sering ditemukan dan paling lama melakukan kontak dengan pasien, sehingga sangat berisiko dengan pekerjaannya, namun banyak perawat tidak menyadari terhadap risiko yang mengancam dirinya yaitu, melupakan keselamatan dan kesehatan kerja (K3). Kepatuhan terhadap APD itu sendiri merupakan hal wajib yang harus dilakukan oleh perawat, yang berguna dalam mencegah terjadinya kecelakaan kerja maupun mencegah tertular penyakit dari satu pasien ke lainnya.

Oleh karena itu, harus lebih diperhatikan lagi bagi para pembuat kebijakan, keselamatan masyarakat, dan tak terlepas dari keselamatan tenaga medis itu sendiri. 


\section{DAFTAR PUSTAKA}

Azizah, Nur. Setiawan. Silaban, Gerry. (2019). HUBUNGAN ANTARA PENGAWASAN, PROSEDUR KERJA DAN KONDISI FISIK DENGAN TERJADINYA KECELAKAAN KERJA PADA PERAWAT DI RUANG RAWAT INAP RUMAH SAKITPERMATA BUNDA MEDAN TAHUN 2017. Jurnal JUMANTIK Vol. 3 No.2, 125-134.

Iftadi, Irwan. Jauhari, W, A,. Fatmasari A,. (2011). Penentuan Faktor-Faktor Bahaya yang Dihadapi Perawat di RSUD Kabupaten Karanganyar dan Usulan Pencegahannya Menggunakan Metode AHP. Performa (2011) Vol.10, No.1, 1-10.

Mantiri, E. Z. R. A,. Pinontoan, Odi R,. Mandey, Sylvia. (2020). FAKTOR PSIKOLOGI DAN PERILAKU DENGAN PENERAPAN MANAJEMEN KESELAMATAN DAN KESEHATAN KERJA RUMAH SAKIT. Indonesian Journal of Public Health and Community Medicine Vol. 1, No. 3, 19-27.

Maria P. I, Silvia. Wiyono, Joko. Candrawati, Erlisa. (2015). KEJADIAN KECELAKAAN KERJA PERAWAT BERDASARKAN TINDAKAN TIDAK AMAN. Jurnal Care Vol. 3, No. 2, 9-17.

Permenkes Nomor 66/ Menkes/ 2016. Tentang Keselamatan dan Kesehatan Kerja.

Ramdan, Iwan M. Rahman, Abd. (2017). Analisis Risiko Kesehatan dan Keselamatan Kerja (K3) pada Perawat. JKP - Volume 5 Nomor 3, 229-241.

Salawati, Liza. (2015). PENYAKIT AKIBAT KERJA DAN PENCEGAHAN. JURNAL KEDOKTERAN SYIAH KUALA Volume 15 Nomor 2, 91-95.

Simamora, R. H. (2017). A strengthening of role of health cadres in BTA-Positive Tuberculosis (TB) case invention through education with module development and video approaches in Medan Padang bulan Comunity Health Center, North Sumatera Indonesia. International Journal of Applied Engineering Research, 12(20), 10026-10035.

Suartini, Luh Putu. (2015). RISIKO ERGONOMI PENYAKIT AKIBAT KERJA PADA PERAWAT GIGI. Jurnal Kesehatan Gigi Vol. 3 No. 2, 113-123.

Ramdan, Iwan M. Rahman, Abd. (2017). Analisis Risiko Kesehatan dan Keselamatan Kerja (K3) pada Perawat. JKP - Volume 5 Nomor 3, 229-241. 
Tukatman, Sulistiawati, dkk. (2015). ANALISIS KESELAMATAN DAN KESEHATAN KERJA PERAWAT DALAM PENANGANAN PASIEN DI RUMAH SAKIT BENYAMIN GULUH KABUPATEN KOLAKA. Jurnal Ners Vol. 10 No. 2, 343-347. 